ПОГРІБНІЧЕНКО І.М.

\title{
СИСТЕМА ПРИНЦИПІВ ПРОВАДЖЕННЯ В АДМІНІСТРАТИВНИХ СПРАВАХ, ПОВ'ЯЗАНИХ З ОСКАРЖЕННЯМ ІНДИВІДУАЛЬНИХ АКТІВ
}

У статті відзначено, що одними з фундаментальних аспектів провадження в адміністративних справах, пов'язаних з оскарженням індивідуальних актів, $\epsilon$ принципи, тобто те, що лежить в його основі як ядро, базис, першооснова, на якій має бути побудована вся процесуальна діяльність адміністративного суду під час арбітрування, встановлення істини у цьому різновиді публічно-правової суперечності. Зокрема, питанню їх системи присвячено науковий пошук у межах роботи. На основі аналізу провідних думок учених, а також актів законодавства зазначено, що аналізовані принципи можна класифікувати таким чином: принципи суддівської діяльності; загально-правові та адміністративно-процесуальні; принципи досудового провадження; принципи судового провадження; принципи післясудового провадження; принципи настанови; принципи рекомендації; принципи, що стосуються всіх учасників процесу; принципи, що стосуються окремих учасників процесу; національні принципи; міжнародні принципи тощо. Сформовано висновок, згідно з яким система принципів провадження в адміністративних справах, пов'язаних з оскарженням індивідуальних актів, $є$ переліком класифікованих за певними ознаками настанов, рекомендацій та умов, на яких грунтуються порядок процесуальної діяльності адміністративного суду та поведінка учасників адміністративної справи. Окремо виділено такі принципи провадження в адміністративних справах, пов'язаних з оскарженням індивідуальних актів: принцип поділу влади, точніше розподілу функцій між ними, який передбачає, що адміністративні суди утворені задля реалізації правосуддя в чіткому полі юрисдикційності, реалізовуючи завдання в означеній площині, а саме перевірку індивідуального акта щодо правовірності його прийняття; принцип розгляду справи, який тягне за собою ухвалення рішення, що має юридичні наслідки в порядку дотримання судової процедури; принципи охорони та забезпечення національних інтересів і підтримання міжнародно-правового режиму захисту гарантованих прав; принципи законності, верховенства права, гласності, відкритості, неупередженості та незалежності правосуддя; принцип відповідності, тобто вибране судом рішення відповідає способу забезпечення, охороні права позивача; принцип судового контролю; принцип скасування незаконного адміністративного акта.

Ключові слова: адміністративна справа, адміністративний акт, акт, індивідуальне рімення, оскарження, принципи, публічна адміністрація, спір, судове оскарження.

In the article the author noted that one of fundamental aspects of administrative proceedings related to the appeal of individual acts is the principles, that is, which is at its core, the basis on which all procedural activity of an administrative court during arbitration should be built, establishing the truth in this variety of public-law controversy. In particular, the issue of their system is addressed in the scientific research within this work. On the basis of the analysis of the leading opinions of scientists as well as acts of the legislation, it is stated that the analyzed principles can be classified in particular into: 1) principles of judicial activity; general legal and administrative procedural; 2) principles before court proceedings; principles of court proceedings; principles after court proceedings; 3) principles of instruction; principles of recommendation; 4) principles for all participants in the process; principles relating to individual participants in the process; 5) national principles; international principles, etc. It is concluded that the system

(С) ПОГРІБНІЧЕНКО І.М. - здобувач (Науково-дослідний інститут публічного права) 
of principles of administrative proceedings related to the appeal of individual acts - is a list of classified according to certain characteristics of the guidelines, recommendations and conditions on which the procedure of administrative court proceedings and the conduct of participants in the administrative case. The following principles of administrative proceedings relating to the appeal of individual acts are singled out: 1) the principle of separation of powers, and more precisely the division of functions between them, which presupposes that administrative courts are formed for the implementation of justice in a clear field of jurisdiction, while realizing the same - verification of an individual act for the accuracy of its adoption; 2) the principle of consideration of the case, which entails the adoption of a decision having legal consequences in the order of adherence to court procedure; 3 ) principles of protection and protection of national interests and maintenance of the international legal regime of protection of guaranteed rights; 4) the principles of legality, the rule of law, transparency, openness, impartiality and independence of justice; 5) the principle of conformity - that is, the decision chosen by the court corresponds to the method of ensuring the protection of the claimant's rights; 6) the principle of judicial review and 7) the principle of cancellation of an illegal administrative act.

Key words: act, administrative act, administrative case, appeal, dispute, individual decision, judicial appeal, principles, public administration.

Вступ. Одними з фундаментальних аспектів провадження в адміністративних справах, пов'язаних з оскарженням індивідуальних актів, $є$ принципи, тобто те, що лежить в його основі як ядро, базис, першооснова, на якій має бути побудована вся процесуальна діяльність адміністративного суду під час арбітрування, встановлення істини у цьому різновиді публічно-правової суперечності. Однак нам потрібно з'ясувати, що ж його формує.

Постановка завдання. Зрозуміло, системний підхід до вивчення окреслених принципів не $є$ самоціллю в цьому дослідженні. Він необхідний для того, щоби найбільш повно й точно описати процеси, які відбуваються під час реалізації принципів. В практичному аспекті системний аналіз дасть змогу виявити властивості системи таких принципів, визначити вплив на систему окремого принципу залежності від його змісту, розробити пропозиції щодо законодавчого закріплення змісту принципу таким чином, щоби могла оптимально функціонувати вся система. Дослідження саме системи принципів як особливого правового утворення дасть можливість отримати цілісне уявлення про механізм реалізації кожного з її структурних елементів та системи загалом під час регулювання адміністративно-процесуальних відносин $[1$, с. 8$]$.

Більшість науковців не оминає увагою питання принципів права в межах своїх наукових досліджень. Зокрема, окремі аспекти зазначеного питання висвітлено в роботах таких учених, як А. Бандурка, С. Беньковський, М. Джафарова, В. Колесніченко, Т. Коломоєць, А. Коренев, О. Корчинський, О. Кучинська, О. Пасенюк, С. Потапенко, О. Прилипчук, О. Фазикош. Однак до питання визначення безпосередньо системи принципів провадження в адміністративних справах, пов'язаних із оскарженням індивідуальних актів, їх наукові пошуки звернені не були.

Результати дослідження. Системність принципів права, на наш погляд, означає як наявність відповідних компонентів, так і їх зв'язок, тобто ця властивість принципів ставить завдання їх переліку та класифікації [2, с. 346].

Система принципів адміністративного судочинства відображається у законодавчих актах, зокрема в Конституції, КАС України та міжнародних договорах, згода на обов'язковість яких надана Верховною Радою України [3, с. 156].

Насамперед необхідно виділити конституційні засади судочинства, які визначені у статті 129 Конституції України, до яких належать рівність усіх учасників судового процесу перед законом і судом; забезпечення доведеності вини; змагальність сторін та свобода в наданні ними суду своїх доказів і у доведенні перед судом їх переконливості; підтримання публічного обвинувачення в суді прокурором; забезпечення обвинуваченому права на захист; гласність судового процесу та його повне фіксування технічними засобами; розумні строки розгляду справи судом; забезпечення права на апеляційний перегляд справи та у визначених законом випадках - на касаційне оскарження судового рішення; обов'язковість судового рішення [4; 5 , с. 152].

Зазначене здебільшого корелюється 3 основним спеціалізованим актом в досліджуваній сфері, а саме Кодексом адміністративного судочинства, у частині 3 статті 2 якого передбачено, що основними засадами (принципами) адміністративного судочинства $є$ верховенство права; рів- 
ність усіх учасників судового процесу перед законом і судом; гласність і відкритість судового процесу та його повне фіксування технічними засобами; змагальність сторін, диспозитивність та офіційне з'ясування всіх обставин у справі; обов'язковість судового рішення; забезпечення права на апеляційний перегляд справи; забезпечення права на касаційне оскарження судового рішення у випадках, визначених законом; розумність строків розгляду справи судом; неприпустимість зловживання процесуальними правами; відшкодування судових витрат фізичних та юридичних осіб, на користь яких ухвалене судове рішення [6].

Принципи адміністративного судочинства, закріплені в КАС України, є нормами прямої дії. Вони можуть застосовуватися безпосередньо й не обов'язково у сукупності з конкретнішою нормою, адже такої може не бути [5, с. 152].

Окремо спеціальним принципом саме для аналізованої категорії слід виділити принцип підсудності справи за вибором позивача, принцип забезпечення позову шляхом зупиненням дії індивідуального акта, принцип відновлення прав, свобод чи інтересів позивача [6]. Зазначені принципи є рекомендаційними та втілюються в дійсність за необхідності.

3 доктринальної точки зору одну з найбільш виважених та обгрунтованих позицій щодо системи принципів адміністративного процесу сформульовано провідними фахівцями в зазначеній галузі права, а саме О. Бандуркою та М. Тищенко, які виділяють принципи законності; правової рівності; охорони інтересів держави та особи; публічності (офіційного) процесу; об'єктивної істини; гласності процесу; здійснення процесу державною мовою і забезпечення права користування рідною мовою; швидкості та економічності процесу; самостійності в ухваленні рішень; неухильності реалізації правової презумпції невинуватості та правомірності дій громадян $[7$, c. $34-35 ; 8$, c. 403$]$.

У межах власних праць М. Джафарова наголошує на необхідності їх поділу на такі, що безпосередньо віддзеркалюють специфіку й зміст цієї галузі права, визначають його особливості, мету, завдання та призначення, а також окремо адміністративно-процесуальні принципи, тобто закріплені адміністративно-процесуальним законодавством основоположні приписи, які протягом тривалого часу не зазнають суттєвих змін, визначають характер і зміст діяльності всіх суб' єктів адміністративно-процесуальних правовідносин. Функціональне призначення принципів полягає у забезпеченні відносно сталої векторної спрямованості врегулювання адміністративно-процесуальних відносин, які виникають щодо захисту прав, свобод та інтересів фізичних осіб, прав та інтересів юридичних осіб від порушень з боку суб'єктів владних повноважень у ході розгляду й вирішення судом спорів у сфері публічно-правових відносин [9, с. 57].

Має значення також думка О. Коренєва, який виділяє такі засади адміністративного процесу, як дотримання законності; всебічне й об'єктивне дослідження конкретних фактів та обставин справи; гласність адміністративного процесу; мова корінної національності; відповідальність за дотримання правил процесу та прийняття акта; ефективність та економічність процесу [10, с. 254]. С. Беньковський розділив принципи на три великі групи, а саме соціально-правові принципи проваджень у справах про адміністративні правопорушення, загальні принципи проваджень, спеціальні принципи проваджень. До соціально-правових принципів віднесено принципи гуманізму, соціальної справедливості, демократизму; до загальних - принципи законності, публічності (офіційності), презумпції невинуватості, доведеності вини, всебічності, повноти й об'єктивності дослідження обставин справи, забезпечення кожному права на повагу його гідності, забезпечення кожній людині права на свободу й особисту недоторканність, рівності всіх учасників провадження перед законом та органами, які здійснюють провадження в справі, забезпечення особі, яка притягається до відповідальності, права на захист, забезпечення учасникам провадження права користуватися рідною мовою, обов'язковість рішень органів і посадових осіб, які ведуть провадження, забезпечення права на оскарження дій і рішень посадових осіб та органів, які здійснюють провадження у справі. До спеціальних принципів належать принципи поєднання гласності й конфіденційності, безпосередності дослідження доказів [11, с. 75-76]. Іншої думки дотримується Т. Коломоєць, яка наводить власну класифікацію принципів, дотримання яких дає змогу реалізації адміністративного провадження. Отже, йдеться про принципи законності, публічності, гласності, об'єктивності, здійснення провадження національною мовою, безпосередності провадження, дотримання змагальності сторін, простоти та швидкості (оперативності) провадження, дотримання права на захист законних інтересів громадян, рівності осіб, які беруть участь у провадженні [12, с. $63 ; 13$, с. 39]. До цього переліку, на наш погляд, необхідно додати принцип справедливого та неупередженого вирішення спору, а також його реалізацію в порядку судової процедури. 
Отже, на основі вищевикладеного можемо зробити висновок, що існує чимала кількість класифікацій принципів адміністративного провадження. Це можуть бути принципи, закріплені як в адміністративно-процесуальному, так і в загальному законодавстві [13, с. 39].

Зокрема, щодо останніх уточнимо, що, на думку К. Дейвіса, основні принципи права, на яких грунтуються всі провідні правові системи, виконують допоміжну функцію в тих сферах, де письмові джерела не охоплюють усіх суспільних відносин [14, с. 164-165]. Т. Хартлі, виходячи 3 широкого тлумачення поняття загальних принципів права, до найбільш важливих з них відносить основні права людини, юридичну визначеність (юридичну безпеку), законні очікування, право бути вислуханим, юридичний професійний привілей (право на конфіденційний обмін інформації між юристом і його клієнтом) [15, с. 143-171]. На думку Н. Фостера, класифікація загальних принципів у великих групах поки що не $є$ особливо корисною через різноманітність принципів і ступенів їх перекриття. Проте вчений вважає це можливим, оскільки вона допомагає вивченню й перегляду принципів. Він розбиває всі загальні принципи на три групи, а саме принципи, що стосуються основних прав людини, рівності та процедурних прав. Проте, як підкреслює вчений, ці категорії не «водонепроникні», тому має місце значне перекриття [2, с. 348; 16, с. 89].

Однак ми є прибічниками думки про те, що спиратися слід на практику європейського законодавства, до переліку загальних принципів якого увійшли принцип законності, принцип недискримінації, принцип скасування незаконного адміністративного акта, принцип юридичної визначеності, право на захист, принцип пропорційності, принцип поваги до фундаментальних прав людини та громадянина, принцип субсидіарності, принцип належного управління, принцип прозорості, принцип застосування [17, с. 48-49], а до спеціальних, тобто саме процесуальних, - гласність і відкритість судового процесу та його повне фіксування технічними засобами; змагальність сторін, диспозитивність та офіційне з'ясування всіх обставин у справі; обов'язковість судового рішення; забезпечення права на апеляційний та касаційний перегляд справи; розумність строків розгляду справи судом; неприпустимість зловживання процесуальними правами; відшкодування судових витрат фізичних та юридичних осіб, на користь яких ухвалене судове рішення [6].

Окремою групою в межах зазначених є функціональна, в якій наявні принципи, що встановлюють поведінку як суду (етичні, професійні принципи), так і сторін адміністративної справи, а саме принципи поваги, неприпустимості затягування розгляду справи чи подання стороною явно необгрунтованих заяв і клопотань, безпідставного твердження або заперечення стороною певних обставин, які мають значення для справи [6].

Отже, аналізовані принципи можна класифікувати, зокрема, на принципи суддівської діяльності; загально-правові та адміністративно-процесуальні; принципи досудового провадження; принципи судового провадження; принципи післясудового провадження; принципи-настанови; принципи-рекомендації; принципи, що стосуються всіх учасників процесу; принципи, що стосуються окремих учасників процесу; національні принципи; міжнародні принципи.

Висновки. Все вищевикладене дає можливість сформулювати висновок, згідно з яким система принципів провадження в адміністративних справах, пов'язаних із оскарженням індивідуальних актів, є переліком класифікованих за певними ознаками настанов, рекомендацій та умов, на яких грунтуються порядок процесуальної діяльності адміністративного суду та поведінка учасників адміністративної справи. Найбільш доцільно виділити такі принципи провадження в адміністративних справах, пов'язаних із оскарженням індивідуальних актів:

1) принцип поділу влади, точніше, розподілу функцій між ними, який передбачає, що адміністративні суди утворені задля реалізації правосуддя у чіткому полі юрисдикційності, реалізовуючи завдання в означеній площині, а саме перевірку індивідуального акту щодо правовірності його прийняття;

2) принцип розгляду справи, який тягне за собою ухвалення рішення, що має юридичні наслідки в порядку дотримання судової процедури;

3) принципи охорони та забезпечення національних інтересів і підтримання міжнародно-правового режиму захисту гарантованих прав;

4) принципи законності, верховенства права, гласності, відкритості, неупередженості та незалежності правосуддя;

5) принцип відповідності, за якого ухвалене судом рішення відповідає способу забезпечення, охорони права позивача;

6) принцип судового контролю.

нцип скасування незаконного адміністративного акта, що означає неприпустимість чинності індивідуального акта за наявності у нього дефектів, які прямо або побічно негативно впливають на права, свободи та інтереси громадян. 


\section{Список використаних джерел:}

1. Кучинська О. Системність принципів кримінального провадження як визначальний фактор їх ефективного регуляторного впливу на кримінально-процесуальні відносини. Адвокат. 2012. № 1. С. 7-11.

2. Колесніченко В. Сучасна юридична наука про класифікацію принципів права Європейського Союзу: критичний аналіз. Актуальні проблеми держави і права. 2009. Вип. 47. С. 346-352.

3. Адміністративна юстиція України: проблеми теорії та практики: настільна книга судді / за заг. ред. О. Пасенюка. Київ : Істинна, 2007. 608 с.

4. Конституція України : прийнята Верховною Радою України 28 червня 1996 р. Відомості Верховної Ради Украӥни. 1996. № 30. С. 141.

5. Корчинський О. Принципи адміністративного судочинства як основа захисту прав людини і громадянина. Вісник Національного університету «Львівська політехніка». Серія: Юридичні науки. 2017. № 876. С. 151-156.

6. Кодекс адміністративного судочинства України : Закон України від 6 липня 2005 р. № 2747-IV. Урядовий кур’'єр. 2005. № 153. С. 153-154.

7. Бандурка А. Административный процесс : учебник. Харьков : НУВД, 2001. 352 с.

8. Потапенко С. Система принципів адміністративного процесу України та проблеми їх класифікації. Форум права. 2010. № 2. С. 403-408.

9. Джафарова М. Принципи адміністративного процесуального права у новітніх умовах сьогодення: науково-правовий аспект. Науковий вісник Херсонського державного університету. Серія: Юридичні науки. 2019. Вип. 1. С. 54-57.

10. Коренев А. Административное право России: административно-правовое регулирование в сферах и отраслях управления : учебник. Москва : Московская академия МВД России ; Щит-М, 2002. 348 с.

11. Беньковський С. Правові засади та принципи провадження у справах про адміністративні правопорушення : дис. ... канд. юрид. наук : спец. 12.00.07. Харків, 2009. 219 с.

12. Коломоєць Т. Адміністративне судочинство України. Київ : Істина, 2008. 219 с.

13. Фазикош О. Особливості провадження в справах про адміністративні правопорушення та його принципи. Науковий вісник Ужгородського національного університету. Серія: Право. 2015. Вип. 35 (1.3). С. 36-40.

14. Дэйвис К. Право Европейского Союза / пер. со 2-го англ. изд. Київ : Знання, 2005.

15. Хартли Т.К. Основы права Европейского Сообщества / пер. с англ. Москва : Закон и право ; ЮНИТИ, 1998.

16. Foster N.G. EC Law. Oxford Univ. Press, 2000.

17. Прилипчук О. Європейський адміністративний простір: принципи та засади. Державне управління та місиеве самоврядування. 2016. Вип. 2. С. 46-50. 